\begin{tabular}{|c|l|}
\hline Title & Molecular structure of caffeine as determined by gas electron diffraction aided by theoretical cal culations \\
\hline Author(s) & Egawa, Toru; Kamiya, A kemi; Takeuchi, Hiroshi; Konaka, Shigehiro \\
\hline Citation & $\begin{array}{c}\text { Journal of Molecular Structure, 825(1-3), 151-157 } \\
\text { https://doi.org/10.1016/.mol struc.2006.04.024 }\end{array}$ \\
\hline Issue Date & $2006-12-15$ \\
\hline Doc URL & http://hdl.handle.net/2115/17171 \\
\hline Type & article (author version) \\
\hline Additional Information & There are other files related to this item in HUSCAP. Check the above URL. \\
\hline File Information & JMS825-1-3.pdf (本文) \\
\hline
\end{tabular}

Instructions for use 


\title{
Molecular structure of caffeine as determined by gas electron diffraction aided by theoretical calculations
}

\author{
Toru Egawa ${ }^{*}$, Akemi Kamiya, Hiroshi Takeuchi and Shigehiro Konaka \\ Division of Chemistry, Graduate School of Science, Hokkaido University, \\ Sapporo 060-0810, Japan
}

(Received 8 March 2006; received in revised form 6 April 2006; accepted 6 April 2006)

\begin{abstract}
The molecular structure of caffeine

(3,7-dihydro-1,3,7-trimethyl-1H-purine-2,6-dione) was determined by means of gas electron diffraction. The nozzle temperature was $185^{\circ} \mathrm{C}$. The results of MP2 and B3LYP calculations with the 6-31G** basis set were used as supporting information. These calculations predicted that caffeine has only one conformer and some of the methyl groups perform low frequency internal rotation. The electron diffraction data were analyzed on this basis. The determined structural parameters $\left(r_{\mathrm{g}}\right.$ and $\left.\angle_{\alpha}\right)$ of caffeine are as follows: $\quad<r(\mathrm{~N}-\mathrm{C})_{\text {ring }}>=1.382(3) \AA ; r(\mathrm{C}=\mathrm{C})=1.382(\leftarrow) \AA ; r(\mathrm{C}-\mathrm{C})=1.446(18) \AA$; $r(\mathrm{C}=\mathrm{N})=1.297(11) \AA ;<r\left(\mathrm{~N}-\mathrm{C}_{\text {methyl }}\right)>=1.459(13) \AA ;<r(\mathrm{C}=\mathrm{O})>=1.206(5) \AA ;<r(\mathrm{C}-\mathrm{H})>$ $=1.085(11) \AA ; \angle \mathrm{N}_{1}-\mathrm{C}_{2}-\mathrm{N}_{3}=116.5(11)^{\circ} ; \angle \mathrm{N}_{3}-\mathrm{C}_{4}=\mathrm{C}_{5}=121.5(13)^{\circ} ; \angle \mathrm{C}_{4}=\mathrm{C}_{5}-\mathrm{C}_{6}=$ $122.9(10)^{\circ} ; \angle \mathrm{C}_{4}=\mathrm{C}_{5}-\mathrm{N}_{7}=104.7(14)^{\circ} ; \angle \mathrm{N}_{9}-\mathrm{C}_{4}=\mathrm{C}_{5}=111.6(10)^{\circ} ;<\angle \mathrm{N}-\mathrm{C}-\mathrm{H}_{\text {methyl }}>=$ 108.5(28) $)^{\circ}$ Angle brackets denote average values; parenthesized values are the estimated limits of error $(3 \sigma)$ referring to the last significant digit; left arrow in the parenthesis means that this parameter is bound to the preceding one.
\end{abstract}

\footnotetext{
* Corresponding author. Phone: +81-11-706-3506; Fax: +81-11-706-4924. E-mail address: egawa@sci.hokudai.ac.jp
} 
Keywords: Caffeine; Molecular structure; Gas electron diffraction; MP2 calculations; DFT calculations

\section{Introduction}

Caffeine (3,7-dihydro-1,3,7-trimethyl-1H-purine-2,6-dione, see Fig. 1) is the central nervous system stimulant that is most consumed in our daily life, as it is contained in not only coffee but also tea, cocoa, cola and other various beverages and foods. It is understood that the effect of caffeine and other methylxanthines depends on their concentration in the human body $[1,2]$. At the concentrations attainable after taking a few cups of coffee, the effect is due to the adenosine receptor antagonism, i.e., they inhibit adenosine to bind to its receptor. At higher concentrations, however, they act as inhibitors of phosphodiesterase. Not only biochemical but also spectroscopic and diffraction studies of caffeine are still being reported extensively today, however, they are mostly of the condensed phase (see Refs. [3-6], for example) that suffer from the inter-molecular forces. Although it is a common understanding that the above-mentioned effect of caffeine is brought about by its structural resemblance with adenosine and cyclic-AMP, no reliable experimental molecular structure even in the crystal has been reported. The crystal structures of caffeine hydrate have been reported $[7,8]$, but the structural determination of pure anhydrous caffeine has not been successful because of the difficulty in preparing the fully ordered crystal $[5,6]$.

We have succeeded in determining the gas-phase molecular structures of bioactive compounds including central nervous system stimulants, nicotine [9] and arecoline [10], by means of gas electron diffraction, in which some discussions on the structure-bioactivity relationship were provided. Under these circumstances, structural determination of caffeine by means of gas electron diffraction aided by theoretical calculations has been chosen as our target in the present study. 


\section{Experimental}

The sample of caffeine with purity of $99 \%$ was purchased from Aldrich Chemical Co. and was used without further purification. Electron diffraction patterns were recorded on 8 in. $\times 8$ in. Kodak projector slide plates with an apparatus equipped with an $r^{3}$-sector [11]. The camera distance was $244.3 \mathrm{~mm}$ to cover the $s$-range of $4.5-33.8 \AA^{-1}$, which is sufficient for the molecules of this size. The vapor pressure of caffeine is not high enough for the electron diffraction experiment at room temperature and the sample was heated to $185^{\circ} \mathrm{C}$ by using the nozzle system reported in Ref. [12]. The acceleration voltage of incident electrons was about $38 \mathrm{kV}$ and the electron wavelength calibrated to the $r_{\mathrm{a}}(\mathrm{C}=\mathrm{S})$ distance of $\mathrm{CS}_{2}(1.5570 \AA)$ [13] was $0.06327 \AA$. The photographic plates were developed for $4.5 \mathrm{~min}$. in a Dektol developer diluted 1:1. The photometry process was described in details elsewhere [14]. Other experimental conditions are as follows: beam current was $1.4-1.5 \mu \mathrm{A}$; background pressure during exposure was $2.6 \times 10^{-6}$ Torr; uncertainty in the scale factor $(3 \sigma)$ was $0.03 \%$; exposure time was $62-113 \mathrm{~s}$; number of plates used was 4 . The experimental intensities and backgrounds are available as supplementary information (Table S1).

Elastic atomic scattering factors were calculated as described in Ref. [15], and inelastic ones were taken from Ref. [16]. The experimental molecular scattering intensities are shown in Fig. 2 with the final calculated ones. A diagonal weight matrix was used in the least-squares analysis on the molecular scattering intensities.

\section{Theoretical calculations}

Geometry optimizations of caffeine were carried out by using the MP2(frozen core) and B3LYP methods with the 6-31G** basis set. Program GAUSSIAN 03 [17] was used. The obtained geometrical parameters for the conformer shown in Fig. 1 are listed in Table 1. As for the MP2/6-31G** calculation, essentially the same result has been reported by Poltev et al. [18], but some structural parameters for the $\mathrm{C}-\mathrm{H}$ bonds were 
omitted in it. In order to confirm that this is the only one stable conformer, the potential functions for the internal rotation of the $\mathrm{N}_{1}-\mathrm{C}_{10}, \mathrm{~N}_{3}-\mathrm{C}_{12}$ and $\mathrm{N}_{7}-\mathrm{C}_{14}$ bonds were obtained by a series of geometry optimizations where only one of the corresponding internal rotation angles, $\phi(\mathrm{C}-\mathrm{N}-\mathrm{C}-\mathrm{H})$, was fixed at 0 to $60^{\circ}$ with an interval of $15^{\circ}$. The obtained potential functions are shown in Fig. 3. There is a shallow dip at $\phi=60^{\circ}$ in the $\mathrm{N}_{3}-\mathrm{C}_{12}$ potential function obtained by the B3LYP calculations. The quantum mechanical calculations described below revealed that no energy level exists associated with this minimum, and hence, it was concluded that this dip cannot make a conformer. The $\mathrm{N}_{1}-\mathrm{C}_{10}$ potential functions obtained by the MP2 and B3LYP calculations are both three fold and their barrier heights exceed $100 \mathrm{~cm}^{-1}$. This feature seemed puzzling considering the nearly symmetric arrangement of the bonds located close to the $\mathrm{N}_{1}-\mathrm{C}_{10}$ bond (i.e., the $\mathrm{C}_{2}=\mathrm{O}_{11}$ and $\mathrm{C}_{6}=\mathrm{O}_{13}$ groups), which made a six-fold potential function with a smaller barrier to be more plausible. The natural population analysis [19] provided only a small amount of difference in the atomic charge distribution between the $\mathrm{C}_{2}=\mathrm{O}_{11}$ and $\mathrm{C}_{6}=\mathrm{O}_{13}$ groups. Therefore, a simple explanation by means of only the interaction between the methyl and carbonyl groups does not seem to be effective in this case. According to the MP2 and B3LYP calculations, the internal rotation around the $\mathrm{N}_{1}-\mathrm{C}_{10}$ bond by $60^{\circ}$ changes the bond angles determining the direction of this bond $\left(\mathrm{C}_{2}-\mathrm{N}_{1}-\mathrm{C}_{10}\right.$ and $\mathrm{C}_{6}-\mathrm{N}_{1}-\mathrm{C}_{10}$ ) by about $2.5^{\circ}$. Other bond angles in the 6-membered ring also change significantly. On the other hand, the structural changes caused by the $\mathrm{N}_{3}-\mathrm{C}_{12}$ and $\mathrm{N}_{7}-\mathrm{C}_{14}$ internal rotation are smaller and more local. Therefore, it is likely that the potential function for the $\mathrm{N}_{1}-\mathrm{C}_{10}$ internal rotation is not the consequence of the local interaction but that of the global structural factors.

The vibrational calculation was carried out with the B3LYP method and the 6-31G** basis set. No imaginary frequency was yielded. The obtained Cartesian force constants were used for the following normal vibration analysis. 


\section{Analyses}

Normal vibration analysis. The Cartesian force constants obtained by the B3LYP/6-31G** calculation were transformed into the force constants, $f_{i j}$, for the internal coordinates. The theoretical $f_{i j}$ 's were modified by the scaling method so as to reproduce the reported vibrational wavenumbers $[3,4,20]$. The linear scaling formula, $f_{i j}$ (scaled) $=\left(c_{i} c_{j}\right)^{1 / 2} f_{i j}$ (unscaled), was used where $c_{i}$ is a scale factor [21]. The definitions of internal coordinates with the resultant scale factors are listed in Table S2 of Supplementary Information. The observed and calculated vibrational wavenumbers are listed in Table S3 of Supplementary Information. Most of the observed wavenumbers were reproduced within the accuracy of $\pm 2 \%$.

Analysis of electron diffraction data. In order to reduce the number of adjustable parameters, the following treatment was adopted using the results of the MP2/6-31G** geometry optimization: (1) the molecular symmetry was assumed to be $C_{\mathrm{s}}$; (2) the differences among the $\mathrm{N}-\mathrm{C}$ bond lengths in the rings and the $\mathrm{C}_{4}=\mathrm{C}_{5}$ bond length were set equal to their theoretical values; (3) the difference between the two $\mathrm{C}=\mathrm{O}$ bond lengths was set equal to its theoretical value; (4) the differences among the three $\mathrm{N}-\mathrm{C}_{\text {methyl }}$ bond lengths were set equal to their theoretical values; (5) the differences among all the $\mathrm{C}-\mathrm{H}$ bond lengths were set equal to their theoretical values; (6) the difference between the $\mathrm{C}_{2}-\mathrm{N}_{1}-\mathrm{C}_{10}$ and $\mathrm{C}_{6}-\mathrm{N}_{1}-\mathrm{C}_{10}$ angles was set equal to its theoretical value and the bond angles related to the $\mathrm{C}_{2}=\mathrm{O}_{11}, \mathrm{~N}_{3}-\mathrm{C}_{12}, \mathrm{C}_{6}=\mathrm{O}_{13}, \mathrm{~N}_{7}-\mathrm{C}_{14}$ and $\mathrm{C}_{8}-\mathrm{H}_{15}$ bonds were treated similarly; (7) the differences among all the $\mathrm{N}-\mathrm{C}-\mathrm{H}$ angles in the methyl groups were set equal to their theoretical values. A preliminary analysis in which the $\mathrm{C}_{4}=\mathrm{C}_{5}$ bond length was treated as an independent parameter resulted in the unacceptably large uncertainty for it. Therefore, the $\mathrm{C}_{4}=\mathrm{C}_{5}$ bond length was bound with the $\mathrm{N}-\mathrm{C}$ bonds in the rings as mentioned in the assumption (2). The independent parameters and the constraints are summarized in Table 2.

As shown in Fig. 3, the barrier heights for the internal rotation of the $\mathrm{N}_{3}-\mathrm{C}_{12}$ and 
$\mathrm{N}_{7}-\mathrm{C}_{14}$ bonds obtained by the B3LYP/6-31G** calculations are as low as about $30 \mathrm{~cm}^{-1}$ and the thermal averaged distribution of the $\mathrm{H}$ atoms of $\mathrm{C}_{12}$ and $\mathrm{C}_{14}$ methyl groups is expected to be close to that of the free rotation. Therefore, the treatment of the large-amplitude motion was adopted, in which the contributions from the non-bonded $\mathrm{X} \cdots \mathrm{H}_{\text {methyl }}$ atomic pairs were taken into account by means of pseudo conformers, where $\mathrm{X}$ $=\mathrm{C}, \mathrm{N}$ or $\mathrm{O}$. First, the potential energy for the $\mathrm{N}_{3}-\mathrm{C}_{12}$ and $\mathrm{N}_{7}-\mathrm{C}_{14}$ internal rotation obtained by the B3LYP/6-31G** calculations was fitted by using the functional form,

$$
V(\phi)=\frac{1}{2} \sum_{k=1}^{4} V_{3 k}\{1-\cos 3 k \phi\},
$$

where $\phi$ is the internal rotation angle. The obtained best-fit potential functions are shown in Fig. 3 and the corresponding potential constants, $V_{3 k}$ 's, are listed in Table S4 of Supplementary Information. Next, the energy levels and eigen functions were obtained by using the Hamiltonian,

$$
H=-B \frac{\partial^{2}}{\partial \phi^{2}}+V(\phi)
$$

where

$$
B=\frac{h}{8 \pi^{2} c_{r}}
$$

and $I_{r}$ is the reduced moment of inertia for internal rotation, which was assumed to be constant. By applying the method described in Ref. [22] and by using the B3LYP/6-31G** geometrical structure, $B$ constant was estimated to be $5.29 \mathrm{~cm}^{-1}$ and 5.31 $\mathrm{cm}^{-1}$ for $\mathrm{N}_{3}-\mathrm{C}_{12}$ and $\mathrm{N}_{7}-\mathrm{C}_{14}$ internal rotation, respectively. Free rotation eigen functions were used as a basis set to solve eq. (2). The pseudo conformers were made at $\phi=0^{\circ}, \pm$ $24^{\circ}$ and $\pm 48^{\circ}$ and their abundances were calculated from the obtained energy levels and eigen functions.

Mean amplitudes, $l$, and shrinkage corrections, $r_{\mathrm{a}}-r_{\alpha}$ [23], were calculated from the above-mentioned scaled force constants by adopting the model of small-amplitude vibrations. The contributions from the $\mathrm{N}_{3}-\mathrm{C}_{12}$ torsion and $\mathrm{N}_{7}-\mathrm{C}_{14}$ torsion were 
excluded, for which the curvilinearity of the displacements was taken into account by means of the above-mentioned large-amplitude treatment. The mean amplitudes were adjusted in groups. The groups were separated according to the $r_{\mathrm{a}}$ distances of the atomic pairs. The differences among the mean amplitudes in each group were fixed at the calculated values. Table S5 of Supplementary Information lists the mean amplitudes with the corresponding $r_{\mathrm{a}}$ distances. The anharmonicity parameters, $\kappa$ [24], for bonded atom pairs were estimated in a diatomic approximation, $\kappa=(a / 6) l^{4}[25]$, where the Morse parameter, $a$, was assumed to be $2.0 \AA^{-1}$. Those for nonbonded atom pairs were assumed to be zero.

\section{Results and discussions}

Table 3 lists the obtained structural parameters for caffeine. The experimental radial distribution curve with residuals is shown in Fig. 4 . The resultant $R$-factor ${ }^{1}$ was 0.046. The correlation matrix is listed in Table S6 of Supplementary Information. No off-diagonal element of the correlation matrix has the absolute value larger than 0.9.

In Table 3, the structural parameters of caffeine monohydrate in the crystal [8] and the gas-phase structures of the related molecules, uracil [26] and imidazole [27, 28] (see Fig. 1), are also listed. Compared with all the corresponding theoretical and experimental values, the $r_{\mathrm{g}}(\mathrm{N}=\mathrm{C})$ determined in the present study $(1.297 \pm 0.011 \AA)$ seems too short. A trial analysis of the electron diffraction data was carried out, in which the structural constraints were taken from the results of an RHF/6-31G** calculation and consequently, the relative differences among the $\mathrm{N}-\mathrm{C}$ bond length in the rings were significantly different from those by the MP2 calculation. It resulted in the longer (by $0.009 \AA$ ) $\mathrm{N}=\mathrm{C}$ length, suggesting that the $\mathrm{N}=\mathrm{C}$ length is dependent on the

\footnotetext{
${ }^{1} R$-factor is defined as $R=\left[\sum_{i} W_{i}\left(\Delta s M(s)_{i}\right)^{2} / \sum_{i} W_{i}\left(s M(s)_{i}{ }^{\text {obs }}\right)^{2}\right]^{1 / 2}$, where $\Delta s M(s)_{i}=s M(s)_{i}{ }^{\text {obs }}-s M(s)_{i}{ }^{\text {calc }}$ and $W_{i}$ is a diagonal element of the weight matrix.
} 
structural constraints of the $\mathrm{N}-\mathrm{C}$ bond lengths although the $\mathrm{N}=\mathrm{C}$ length was treated as an independent parameter. Therefore, it might be appropriate to expect a larger error limit for the $\mathrm{N}=\mathrm{C}$ length. By using the diatomic approximation [29] and neglecting the centrifugal distortion term, the difference between the $r_{\mathrm{g}}$ and $r_{\mathrm{e}}$ distances can be approximated to be, $r_{\mathrm{g}}-r_{\mathrm{e}} \approx(3 / 2) a l^{2}$, and by assuming the Morse parameter, $a$, to be 2.0 $\AA^{-1}$, this term is estimated to be around $0.018 \AA$ for the $\mathrm{C}-\mathrm{H}$ bonds and $0.007-0.008 \AA$ for other single bonds. Considering this correction, it can be said that the $\mathrm{N}-\mathrm{C}$ and $\mathrm{C}-\mathrm{H}$ bond lengths reproduced by the MP2/6-31G** calculation are slightly longer than the experimental values while the $\mathrm{C}-\mathrm{C}$ bond length is accurately reproduced. The MP2 values of the $\mathrm{C}=\mathrm{O}$ bond lengths are much larger than the experimental values. The theoretical bond angles are in moderate agreement with the experimental ones. The $\mathrm{B} 3 \mathrm{LYP} / 6-31 \mathrm{G}^{* *}$ structure agrees with the experimental one to the similar extent to that of the MP2 calculation.

As mentioned in Introduction, no crystal structure has been reported for anhydrous caffeine. So the gas-phase structure of the present study is compared with the crystal structure of the monohydrated caffeine [8]. Disagreements are found for many structural parameters especially in bond lengths even with the difference between the definitions of the bond length ( $r_{\mathrm{g}}$ for electron diffraction and $r_{\alpha}$ for X-ray diffraction) taken into account. Monohydrated caffeine forms hydrogen bonded polymeric chains in the crystal, in which the $\mathrm{N}_{9}$ atom accepts a hydrogen from the water molecule [8]. However, the discrepancies in the bond lengths between the gas and crystal phases are not limited to the $\mathrm{N}_{9}$ vicinity, and hence, the packing effect seems to be playing a more important role than the hydration in the crystal structure.

The one-to-one comparison between the $\mathrm{N}-\mathrm{C}$ bond lengths of caffeine and uracil [26] shows disagreement. However, the averaged value of the $r_{\mathrm{g}}(\mathrm{N}-\mathrm{C})$ for the 6-membered ring of caffeine $(1.394 \pm 0.003 \AA)$ is in a good agreement with that of uracil $(1.399 \pm 0.006 \AA)$. Their $\mathrm{C}=\mathrm{O}$ lengths are also close to each other. On the other hand, 
differences in the corresponding bond angles between caffeine and uracil are up to $4.5^{\circ}$.

Many of the experimental bond lengths in imidazole [27, 28] are in disagreement with the corresponding values in caffeine. It should also be noted that caffeine has a longer $\mathrm{C}=\mathrm{C}$ length than both of uracil and imidazole. This lengthening of the $\mathrm{C}=\mathrm{C}$ bond at the formation of the bicyclo ring system has been reproduced by the MP2/6-31G** calculations carried out for this discussion, qualitatively. The theoretical $\mathrm{C}=\mathrm{C}$ lengths of uracil and imidazole are found to be $1.351 \AA$ and $1.378 \AA$, respectively, and the corresponding values for the bicyclo ring system, caffeine and xanthine (1.383 $\AA$ and $1.381 \AA$, respectively) are larger than them. Because of the lengthening of the $\mathrm{C}=\mathrm{C}$ bond, the skeletal structure of caffeine is different from the simple combination of those of uracil and imidazole.

\section{Supplementary information}

Tables of the leveled total intensities and the backgrounds, definitions of the internal coordinates with the scale factors, observed and calculated vibrational wavenumbers, potential constants for the internal rotation, mean amplitudes, and the correlation matrix are deposited.

\section{Acknowledgements}

The authors thank the Research Center for Computational Science, Okazaki, Japan, for the use of the Fujitsu VPP5000 computer and the Library Program GAUSSIAN 03.

\section{References}

[1] A. Nehlig, J.-L. Daval, G. Debry, Brain Res. Rev., 17 (1992) 139.

[2] B. B. Fredholm, Pharmacol. Toxicol., 76 (1995) 93.

[3] H. G. M. Edwards, D. W. Farwell, L. F. C. de Oliveira, J.-M. Alia, M. Le Hyaric, M. 
V. de Ameida, Anal. Chim. Acta, 532 (2005) 177.

[4] S. Gunasekaran, G. Sankari, S. Ponnusamy, Spectrochim. Acta, A61 (2005) 117.

[5] L. Carlucci, A. Gavezzotti, Chem. Eur. J., 11 (2005) 271.

[6] P. Derollez, N. T. Correia, F. Danède, F. Capet, F. Affouard, J. Lefebvre, M. Descamps, Acta Cryst., B61 (2005) 329.

[7] D. J. Sutor, Acta Cryst., 11 (1958) 453.

[8] H. G. M. Edwards, E. Lawson, M. de Matas, L. Shields, P. York, J. Chem. Soc., Perkin Trans. 2, (1997) 1985.

[9] T. Takeshima, R. Fukumoto, T. Egawa, S. Konaka, J. Phys. Chem. A, 106 (2002) 8734.

[10] T. Takeshima, H. Takeuchi, T. Egawa, S. Konaka, J. Mol. Struct., 734 (2005) 15.

[11] S. Konaka, M. Kimura, 13th Austin Symposium on Gas Phase Molecular Structure, 12-14 March, The University of Texas, Austin, TX, 1990, S21.

[12] N. Kuze, M. Ebizuka, H. Fujiwara, H. Takeuchi, T. Egawa, S. Konaka, G. Fogarasi, J. Phys. Chem. A, 102 (1998) 2080.

[13] A. Tsuboyama, A. Murayama, S. Konaka, M. Kimura, J. Mol. Struct., 118 (1984) 351.

[14] N. Kuze, H. Fujiwara, H. Takeuchi, T. Egawa, S. Konaka, G. Fogarasi, J. Phys. Chem. A, 103 (1999) 3054.

[15] M. Kimura, S. Konaka, M. Ogasawara, J. Chem. Phys., 46 (1967) 2599.

[16] C. Tavard, D. Nicolas, M. Rouault, J. Chim. Phys. Phys.-Chim. Biol., 64 (1967) 540.

[17] Gaussian 03, Revision C.01, M. J. Frisch, G. W. Trucks, H. B. Schlegel, G. E. Scuseria, M. A. Robb, J. R. Cheeseman, J. A. Montgomery Jr., T. Vreven, K. N. Kudin, J. C. Burant, J. M. Millam, S. S. Iyengar, J. Tomasi, V. Barone, B. Mennucci, M. Cossi, G. Scalmani, N. Rega, G. A. Petersson, H. Nakatsuji, M. Hada, M. Ehara, K. Toyota, R. Fukuda, J. Hasegawa, M. Ishida, T. Nakajima, Y. Honda, 
O. Kitao, H. Nakai, M. Klene, X. Li, J. E. Knox, H. P. Hratchian, J. B. Cross, C. Adamo, J. Jaramillo, R. Gomperts, R. E. Stratmann, O. Yazyev, A. J. Austin, R. Cammi, C. Pomelli, J. W. Ochterski, P. Y. Ayala, K. Morokuma, G. A. Voth, P. Salvador, J. J. Dannenberg, V. G. Zakrzewski, S. Dapprich, A. D. Daniels, M. C. Strain, O. Farkas, D. K. Malick, A. D. Rabuck, K. Raghavachari, J. B. Foresman, J. V. Ortiz, Q. Cui, A. G. Baboul, S. Clifford, J. Cioslowski, B. B. Stefanov, G. Liu, A. Liashenko, P. Piskorz, I. Komaromi, R. L. Martin, D. J. Fox, T. Keith, M. A. Al-Laham, C. Y. Peng, A. Nanayakkara, M. Challacombe, P. M. W. Gill, B. Johnson, W. Chen, M. W. Wong, C. Gonzalez, J. A. Pople, Gaussian, Inc., Wallingford CT, 2004.

[18] V. I. Poltev, T. I. Grokhlina, E. González, A. Deriabina, A. Cruz, L. Gorb, J. Leszczynski, L. N. Djimant, A. N. Veselkov, J. Mol. Struct. (THEOCHEM), 709 (2004) 123.

[19] NBO, Version 3.1, E. D. Glendening, A. E. Reed, J. E. Carpenter, F. Weinhold,

[20] I. Pavel, A. Szeghalmi, D. Moigno, S. Cînta, W. Kiefer, Biopolym. (Biospectrosc.), $72(2003) 25$.

[21] J. E. Boggs, in I. Hargittai and M. Hargittai (Ed.), Stereochemical Applications of Gas-phase Electron Diffraction, Part B, VCH, New York, 1988, Chapter 10.

[22] M. A. Harthcock, J. Laane, J. Mol. Spectrosc., 91 (1982) 300.

[23] K. Kuchitsu, S. J. Cyvin, in S. J. Cyvin (Ed.), Molecular Structures and Vibrations, Elsevier, Amsterdam, 1972, Chapter 12.

[24] K. Kuchitsu, Bull. Chem. Soc. Jpn., 40 (1967) 505.

[25] K. Kuchitsu, L. S. Bartell, J. Chem. Phys., 35 (1961) 1945.

[26] G. Ferenczy, L. Harsányi, B. Rozsondai, I. Hargittai, J. Mol. Struct., 140 (1986) 71.

[27] D. Christen, J. H. Griffiths, J. Sheridan, Z. Naturforsch., 36A (1981) 1378.

[28] J. H. Callomon, E. Hirota, T. Iijima, K. Kuchitsu, W. J. Lafferty, in K.-H. Hellwege and A. M. Hellwege (Ed.), Landolt-Börnstein New Series II, 15, Springer-Verlag, 
Berlin, 1987, 329.

[29] K. Kuchitsu, M. Nakata, S. Yamamoto, in I. Hargittai and M. Hargittai (Ed.), Stereochemical Applications of Gas-phase Electron Diffraction, Part A, VCH, New York, 1988, Chapter 7. 
Table 1

Geometrical parameters and energies of caffeine obtained from the MP2/6-31G** and B3LYP/6-31G** calculations

\begin{tabular}{|c|c|c|}
\hline Parameters ${ }^{\text {a }}$ & $\mathrm{MP} 2 / 6-31 \mathrm{G}^{* *}$ & B3LYP/6-31G** \\
\hline \multicolumn{3}{|c|}{ Bond lengths / Å } \\
\hline $\mathrm{N}_{1}-\mathrm{C}_{2}$ & 1.411 & 1.408 \\
\hline $\mathrm{C}_{2}-\mathrm{N}_{3}$ & 1.384 & 1.392 \\
\hline $\mathrm{N}_{3}-\mathrm{C}_{4}$ & 1.377 & 1.376 \\
\hline $\mathrm{C}_{4}=\mathrm{C}_{5}$ & 1.383 & 1.382 \\
\hline $\mathrm{C}_{5}-\mathrm{C}_{6}$ & 1.435 & 1.433 \\
\hline $\mathrm{C}_{6}-\mathrm{N}_{1}$ & 1.409 & 1.418 \\
\hline $\mathrm{C}_{5}-\mathrm{N}_{7}$ & 1.374 & 1.387 \\
\hline $\mathrm{N}_{7}-\mathrm{C}_{8}$ & 1.363 & 1.356 \\
\hline $\mathrm{C}_{8}=\mathrm{N}_{9}$ & 1.337 & 1.330 \\
\hline $\mathrm{N}_{9}-\mathrm{C}_{4}$ & 1.360 & 1.360 \\
\hline $\mathrm{N}_{1}-\mathrm{C}_{10}$ & 1.464 & 1.466 \\
\hline $\mathrm{C}_{2}=\mathrm{O}_{11}$ & 1.231 & 1.223 \\
\hline $\mathrm{N}_{3}-\mathrm{C}_{12}$ & 1.458 & 1.462 \\
\hline $\mathrm{C}_{6}=\mathrm{O}_{13}$ & 1.235 & 1.229 \\
\hline $\mathrm{N}_{7}-\mathrm{C}_{14}$ & 1.456 & 1.457 \\
\hline $\mathrm{C}_{8}-\mathrm{H}_{15}$ & 1.078 & 1.082 \\
\hline $\mathrm{C}_{10}-\mathrm{H}_{16}$ & 1.084 & 1.088 \\
\hline $\mathrm{C}_{10}-\mathrm{H}_{17,18}$ & 1.087 & 1.092 \\
\hline $\mathrm{C}_{12}-\mathrm{H}_{19}$ & 1.085 & 1.089 \\
\hline $\mathrm{C}_{12}-\mathrm{H}_{20,21}$ & 1.087 & 1.092 \\
\hline $\mathrm{C}_{14}-\mathrm{H}_{22}$ & 1.087 & 1.091 \\
\hline
\end{tabular}


Bond angles / ${ }^{\circ}$

\begin{tabular}{|c|c|c|}
\hline $\mathrm{N}_{1}-\mathrm{C}_{2}-\mathrm{N}_{3}$ & 116.9 & 117.2 \\
\hline $\mathrm{C}_{2}-\mathrm{N}_{3}-\mathrm{C}_{4}$ & 120.0 & 119.8 \\
\hline $\mathrm{N}_{3}-\mathrm{C}_{4}=\mathrm{C}_{5}$ & 120.9 & 121.3 \\
\hline $\mathrm{C}_{4}=\mathrm{C}_{5}-\mathrm{C}_{6}$ & 124.2 & 123.9 \\
\hline $\mathrm{C}_{5}-\mathrm{C}_{6}-\mathrm{N}_{1}$ & 110.5 & 111.0 \\
\hline $\mathrm{C}_{6}-\mathrm{N}_{1}-\mathrm{C}_{2}$ & 127.5 & 126.9 \\
\hline $\mathrm{C}_{4}=\mathrm{C}_{5}-\mathrm{N}_{7}$ & 105.2 & 105.1 \\
\hline $\mathrm{C}_{6}-\mathrm{C}_{5}-\mathrm{N}_{7}$ & 130.6 & 131.0 \\
\hline $\mathrm{C}_{5}-\mathrm{N}_{7}-\mathrm{C}_{8}$ & 106.0 & 105.7 \\
\hline $\mathrm{N}_{7}-\mathrm{C}_{8}=\mathrm{N}_{9}$ & 113.4 & 113.8 \\
\hline $\mathrm{C}_{8}=\mathrm{N}_{9}-\mathrm{C}_{4}$ & 103.3 & 103.6 \\
\hline $\mathrm{N}_{9}-\mathrm{C}_{4}=\mathrm{C}_{5}$ & 112.1 & 111.8 \\
\hline $\mathrm{N}_{9}-\mathrm{C}_{4}-\mathrm{N}_{3}$ & 127.0 & 126.9 \\
\hline $\mathrm{C}_{2}-\mathrm{N}_{1}-\mathrm{C}_{10}$ & 114.5 & 115.1 \\
\hline $\mathrm{C}_{6}-\mathrm{N}_{1}-\mathrm{C}_{10}$ & 117.9 & 118.0 \\
\hline $\mathrm{N}_{1}-\mathrm{C}_{2}=\mathrm{O}_{11}$ & 121.1 & 121.4 \\
\hline $\mathrm{N}_{3}-\mathrm{C}_{2}=\mathrm{O}_{11}$ & 122.0 & 121.4 \\
\hline $\mathrm{C}_{2}-\mathrm{N}_{3}-\mathrm{C}_{12}$ & 118.0 & 118.1 \\
\hline $\mathrm{C}_{4}-\mathrm{N}_{3}-\mathrm{C}_{12}$ & 122.0 & 122.1 \\
\hline $\mathrm{N}_{1}-\mathrm{C}_{6}=\mathrm{O}_{13}$ & 123.4 & 122.6 \\
\hline $\mathrm{C}_{5}-\mathrm{C}_{6}=\mathrm{O}_{13}$ & 126.1 & 126.3 \\
\hline $\mathrm{C}_{5}-\mathrm{N}_{7}-\mathrm{C}_{14}$ & 126.5 & 126.6 \\
\hline $\mathrm{C}_{8}-\mathrm{N}_{7}-\mathrm{C}_{14}$ & 127.5 & 127.7 \\
\hline $\mathrm{N}_{7}-\mathrm{C}_{8}-\mathrm{H}_{15}$ & 121.6 & 121.6 \\
\hline
\end{tabular}




$\begin{array}{lll}\mathrm{N}_{9}=\mathrm{C}_{8}-\mathrm{H}_{15} & 125.0 & 124.6 \\ \mathrm{~N}_{1}-\mathrm{C}_{10}-\mathrm{H}_{16} & 107.1 & 107.3 \\ \mathrm{~N}_{1}-\mathrm{C}_{10}-\mathrm{H}_{17,18} & 109.7 & 110.0 \\ \mathrm{~N}_{3}-\mathrm{C}_{12}-\mathrm{H}_{19} & 107.3 & 107.7 \\ \mathrm{~N}_{3}-\mathrm{C}_{12}-\mathrm{H}_{20,21} & 109.9 & 110.1 \\ \mathrm{~N}_{7}-\mathrm{C}_{14}-\mathrm{H}_{22} & 107.9 & 108.5 \\ \mathrm{~N}_{7}-\mathrm{C}_{14}-\mathrm{H}_{23,24} & 109.8 & 110.2 \\ \mathrm{H}_{16}-\mathrm{C}_{10}-\mathrm{H}_{17,18} & 110.8 & 110.6 \\ \mathrm{H}_{17}-\mathrm{C}_{10}-\mathrm{H}_{18} & 108.7 & 108.3 \\ \mathrm{H}_{19}-\mathrm{C}_{12}-\mathrm{H}_{20,21} & 110.5 & 110.3 \\ \mathrm{H}_{20}-\mathrm{C}_{12}-\mathrm{H}_{21} & 108.8 & 108.4 \\ \mathrm{H}_{22}-\mathrm{C}_{14}-\mathrm{H}_{23,24} & 110.2 & 109.8 \\ \mathrm{H}_{23}-\mathrm{C}_{14}-\mathrm{H}_{24} & 108.9 & 108.3\end{array}$

Dihedral angles / ${ }^{\circ}$

$\begin{array}{lll}\mathrm{C}_{6}-\mathrm{N}_{1}-\mathrm{C}_{10}-\mathrm{H}_{16} & 0.0 & 0.0 \\ \mathrm{C}_{6}-\mathrm{N}_{1}-\mathrm{C}_{10}-\mathrm{H}_{17} & -120.3 & -120.4 \\ \mathrm{C}_{6}-\mathrm{N}_{1}-\mathrm{C}_{10}-\mathrm{H}_{18} & 120.3 & 120.4 \\ \mathrm{C}_{4}-\mathrm{N}_{3}-\mathrm{C}_{12}-\mathrm{H}_{19} & 0.0 & 0.0 \\ \mathrm{C}_{4}-\mathrm{N}_{3}-\mathrm{C}_{12}-\mathrm{H}_{20} & -120.2 & -120.3 \\ \mathrm{C}_{4}-\mathrm{N}_{3}-\mathrm{C}_{12}-\mathrm{H}_{21} & 120.2 & 120.3 \\ \mathrm{C}_{8}-\mathrm{N}_{7}-\mathrm{C}_{14}-\mathrm{H}_{22} & 0.0 & 0.0 \\ \mathrm{C}_{8}-\mathrm{N}_{7}-\mathrm{C}_{14}-\mathrm{H}_{23} & -120.1 & -120.2 \\ \mathrm{C}_{8}-\mathrm{N}_{7}-\mathrm{C}_{14}-\mathrm{H}_{24} & 120.1 & 120.2\end{array}$

${ }^{a}$ See Fig. 1 for the atom numbering. 
Table 2

Structural constraints and independent parameters of caffeine ${ }^{\mathrm{a}}$

Bond lengths ( $\AA$ )

$\mathrm{N}_{1}-\mathrm{C}_{2}$

$\mathrm{C}_{2}-\mathrm{N}_{3}$

$\mathrm{N}_{3}-\mathrm{C}_{4}$

$\mathrm{C}_{4}=\mathrm{C}_{5}$

$\mathrm{C}_{5}-\mathrm{C}_{6}$

$\mathrm{C}_{6}-\mathrm{N}_{1}$

$\mathrm{C}_{5}-\mathrm{N}_{7}$

$\mathrm{N}_{7}-\mathrm{C}_{8}$

$\mathrm{C}_{8}=\mathrm{N}_{9}$

$\mathrm{N}_{9}-\mathrm{C}_{4}$

$\mathrm{N}_{1}-\mathrm{C}_{10}$

$\mathrm{C}_{2}=\mathrm{O}_{11}$

$\mathrm{N}_{3}-\mathrm{C}_{12}$

$\mathrm{C}_{6}=\mathrm{O}_{13}$

$\mathrm{N}_{7}-\mathrm{C}_{14}$

$\mathrm{C}_{8}-\mathrm{H}_{15}$

$\mathrm{C}_{10}-\mathrm{H}_{16}$

$\mathrm{C}_{10}-\mathrm{H}_{17,18}$

$\mathrm{C}_{12}-\mathrm{H}_{19}$

$\mathrm{C}_{12}-\mathrm{H}_{20,21}$

$\mathrm{C}_{14}-\mathrm{H}_{22}$

$\mathrm{C}_{14}-\mathrm{H}_{23,24}$ $r_{1}$

$r_{1}-0.027$

$r_{1}-0.034$

$r_{1}-0.028$

$r_{2}$

$r_{1}-0.002$

$r_{1}-0.036$

$r_{1}-0.048$

$r_{3}$

$r_{1}-0.051$

$r_{4}$

$r_{5}$

$r_{4}-0.005$

$r_{5}+0.005$

$r_{4}-0.008$

$r_{6}$

$r_{6}+0.006$

$r_{6}+0.009$

$r_{6}+0.007$

$r_{6}+0.009$

$r_{6}+0.008$

$r_{6}+0.008$
Bond angles $\left(^{\circ}\right)$

$\mathrm{N}_{1}-\mathrm{C}_{2}-\mathrm{N}_{3}$

$\theta_{1}$

$\mathrm{N}_{3}-\mathrm{C}_{4}=\mathrm{C}_{5} \quad \theta_{2}$

$\mathrm{C}_{4}=\mathrm{C}_{5}-\mathrm{C}_{6} \quad \theta_{3}$

$\mathrm{C}_{4}=\mathrm{C}_{5}-\mathrm{N}_{7} \quad \theta_{4}$

$\mathrm{N}_{9}-\mathrm{C}_{4}=\mathrm{C}_{5} \quad \theta_{5}$

$\mathrm{C}_{2}-\mathrm{N}_{1}-\mathrm{C}_{10}$

$180-0.5\left(\mathrm{C}_{6}-\mathrm{N}_{1}-\mathrm{C}_{2}\right)-1.7$

$\mathrm{N}_{3}-\mathrm{C}_{2}=\mathrm{O}_{11}$

$180-\theta_{1} / 2+0.4$

$\mathrm{C}_{4}-\mathrm{N}_{3}-\mathrm{C}_{12}$

$180-0.5\left(\mathrm{C}_{2}-\mathrm{N}_{3}-\mathrm{C}_{4}\right)+2.0$

$\mathrm{C}_{5}-\mathrm{C}_{6}=\mathrm{O}_{13}$

$180-0.5\left(\mathrm{C}_{5}-\mathrm{C}_{6}-\mathrm{N}_{1}\right)+1.3$

$\mathrm{C}_{5}-\mathrm{N}_{7}-\mathrm{C}_{14}$

$180-0.5\left(\mathrm{C}_{5}-\mathrm{N}_{7}-\mathrm{C}_{8}\right)-0.5$

$\mathrm{N}_{7}-\mathrm{C}_{8}-\mathrm{H}_{15}$

$180-0.5\left(\mathrm{~N}_{7}-\mathrm{C}_{8}=\mathrm{N}_{9}\right)-1.7$

$\mathrm{N}_{1}-\mathrm{C}_{10}-\mathrm{H}_{16}$

$\theta_{6}$

$\mathrm{N}_{1}-\mathrm{C}_{10}-\mathrm{H}_{17,18} \quad \theta_{6}+2.7$

$\mathrm{N}_{3}-\mathrm{C}_{12}-\mathrm{H}_{19}$

$\theta_{6}+0.2$

$\mathrm{N}_{3}-\mathrm{C}_{12}-\mathrm{H}_{20,21}$

$\theta_{6}+2.8$

$\mathrm{N}_{7}-\mathrm{C}_{14}-\mathrm{H}_{22}$

$\theta_{6}+0.8$

$\mathrm{N}_{7}-\mathrm{C}_{14}-\mathrm{H}_{23,24}$

$\theta_{6}+2.8$

Dihedral angles $\left(^{\circ}\right)$

$\mathrm{C}_{6}-\mathrm{N}_{1}-\mathrm{C}_{10}-\mathrm{H}_{17} \quad-120.3$

$\mathrm{C}_{6}-\mathrm{N}_{1}-\mathrm{C}_{10}-\mathrm{H}_{18} \quad 120.3$

$\mathrm{C}_{4}-\mathrm{N}_{3}-\mathrm{C}_{12}-\mathrm{H}_{20} \quad-120.2$

$\mathrm{C}_{4}-\mathrm{N}_{3}-\mathrm{C}_{12}-\mathrm{H}_{21}$

120.2 
$\mathrm{C}_{8}-\mathrm{N}_{7}-\mathrm{C}_{14}-\mathrm{H}_{23} \quad-120.1$

$\mathrm{C}_{8}-\mathrm{N}_{7}-\mathrm{C}_{14}-\mathrm{H}_{24} \quad 120.1$

${ }^{a}$ See Fig. 1 for the atom numbering. 
Table 3

Experimental structural parameters of caffeine and related molecules

\begin{tabular}{|c|c|c|c|c|}
\hline \multirow[t]{2}{*}{ Parameters $^{\mathrm{a}}$} & \multicolumn{2}{|c|}{ Caffeine } & \multirow{2}{*}{$\begin{array}{c}\text { Uracil }^{\mathrm{b}} \\
\mathrm{ED}\left(r_{\mathrm{g}} \text { and } \angle_{\alpha}\right)\end{array}$} & \multirow{2}{*}{$\begin{array}{l}\text { Imidazole } \\
\mathrm{MW}\left(r_{\mathrm{s}} \text { an }\right.\end{array}$} \\
\hline & $\operatorname{ED}\left(r_{\mathrm{g}} \text { and } \angle_{\alpha}\right)^{\mathrm{d}}$ & X-ray ${ }^{\mathrm{e}}$ & & \\
\hline \multicolumn{5}{|c|}{ Bond lengths $(\AA)$} \\
\hline $\mathrm{N}_{1}-\mathrm{C}_{2}$ & 1.410 ) & $1.388(4)$ & $1.391\rceil$ & \\
\hline $\mathrm{N}_{3}-\mathrm{C}_{2}$ & $1.383 \mid$ & $1.372(4)$ & 1.395 & \\
\hline $\mathrm{N}_{3}-\mathrm{C}_{4}$ & 1.376 & $1.371(3)$ & 1.396 & \\
\hline $\mathrm{N}_{1}-\mathrm{C}_{6}$ & 1.408 & $1.421(4)$ & $1.415\}(6)$ & \\
\hline $\mathrm{N}_{7}-\mathrm{C}_{5}$ & $1.373\}(3)$ & $1.386(3)$ & | & $1.377(3)$ \\
\hline $\mathrm{N}_{7}-\mathrm{C}_{8}$ & 1.362 & $1.337(4)$ & | & $1.364(3)$ \\
\hline $\mathrm{N}_{9}-\mathrm{C}_{4}$ & $1.359 \mid$ & $1.354(4)$ & 1 & $1.382(3)$ \\
\hline$<\mathrm{N}-\mathrm{C}_{\text {ring }}>$ & 1.382 & 1.376 & $1.399 \mathrm{~J}$ & \\
\hline $\mathrm{C}_{4}=\mathrm{C}_{5}$ & $1.382 \mathrm{~J}$ & $1.365(4)$ & $1.343 \quad(24)$ & $1.364(3)$ \\
\hline $\mathrm{C}_{5}-\mathrm{C}_{6}$ & $1.446 \quad(18)$ & $1.413(4)$ & $1.462 \quad(8)$ & \\
\hline $\mathrm{C}_{8}=\mathrm{N}_{9}$ & $1.297 \quad(11)$ & $1.328(4)$ & & $1.314(3)$ \\
\hline $\mathrm{N}_{1}-\mathrm{C}_{10}$ & $1.464\rceil$ & $1.466(4)$ & & \\
\hline $\mathrm{N}_{3}-\mathrm{C}_{12}$ & $1.458\}(13)$ & $1.467(4)$ & & \\
\hline $\mathrm{N}_{7}-\mathrm{C}_{14}$ & 1.456 & $1.462(4)$ & & \\
\hline$<\mathrm{N}-\mathrm{C}_{\text {methyl }}>$ & $1.459 \mathrm{~J}$ & 1.465 & & \\
\hline $\mathrm{C}_{2}=\mathrm{O}_{11}$ & 1.2047 & $1.223(4)$ & $1.212\rceil$ & \\
\hline $\mathrm{C}_{6}=\mathrm{O}_{13}$ & $1.209\}(5)$ & $1.220(4)$ & $1.211\}(3)$ & \\
\hline$<\mathrm{C}=\mathrm{O}>$ & $1.206 \mathrm{~J}$ & 1.221 & $1.212 \mathrm{~J}$ & \\
\hline
\end{tabular}


$<\mathrm{C}-\mathrm{H}>\quad 1.085 \quad(11)$

Bond angles $\left(^{\circ}\right)$

\begin{tabular}{|c|c|c|c|c|c|c|}
\hline $\mathrm{N}_{1}-\mathrm{C}_{2}-\mathrm{N}_{3}$ & 116.5 & (11) & $117.4(2)$ & 114.6 & $(20)$ & \\
\hline $\mathrm{C}_{2}-\mathrm{N}_{3}-\mathrm{C}_{4}$ & 120.3 & $-^{\mathrm{f}}$ & $119.4(2)$ & 123.2 & (12) & \\
\hline $\mathrm{N}_{3}-\mathrm{C}_{4}=\mathrm{C}_{5}$ & 121.5 & (13) & $122.0(3)$ & 122.1 & $(22)$ & \\
\hline $\mathrm{C}_{4}=\mathrm{C}_{5}-\mathrm{C}_{6}$ & 122.9 & $(10)$ & $123.3(3)$ & 119.7 & $(21)$ & \\
\hline $\mathrm{C}_{5}-\mathrm{C}_{6}-\mathrm{N}_{1}$ & 111.0 & $-^{f}$ & $111.2(3)$ & 115.5 & (18) & \\
\hline $\mathrm{C}_{6}-\mathrm{N}_{1}-\mathrm{C}_{2}$ & 127.8 & $-^{\mathrm{f}}$ & $126.7(2)$ & 126.0 & (14) & \\
\hline $\mathrm{C}_{4}=\mathrm{C}_{5}-\mathrm{N}_{7}$ & 104.7 & (14) & $104.8(2)$ & & & $105.5(3)$ \\
\hline $\mathrm{C}_{5}-\mathrm{N}_{7}-\mathrm{C}_{8}$ & 105.6 & $-^{\mathrm{f}}$ & $106.0(2)$ & & & $106.9(3)$ \\
\hline $\mathrm{N}_{7}-\mathrm{C}_{8}=\mathrm{N}_{9}$ & 114.2 & $-^{\mathrm{f}}$ & $113.7(2)$ & & & $112.0(3)$ \\
\hline $\mathrm{C}_{8}=\mathrm{N}_{9}-\mathrm{C}_{4}$ & 103.8 & $-^{\mathrm{f}}$ & $103.3(2)$ & & & $104.9(3)$ \\
\hline $\mathrm{N}_{9}-\mathrm{C}_{4}=\mathrm{C}_{5}$ & 111.6 & (10) & $112.1(3)$ & & & $110.7(3)$ \\
\hline $\mathrm{C}_{2}-\mathrm{N}_{1}-\mathrm{C}_{10}$ & 114.4 & $-^{\mathrm{f}}$ & $116.8(2)$ & & & \\
\hline $\mathrm{N}_{3}-\mathrm{C}_{2}=\mathrm{O}_{11}$ & 122.2 & $-^{\mathrm{f}}$ & $121.0(3)$ & 123.8 & (14) & \\
\hline $\mathrm{C}_{4}-\mathrm{N}_{3}-\mathrm{C}_{12}$ & 121.8 & $-^{f}$ & $121.2(2)$ & & & \\
\hline $\mathrm{C}_{5}-\mathrm{C}_{6}=\mathrm{O}_{13}$ & 125.9 & $-^{\mathrm{f}}$ & $127.9(3)$ & 124.3 & $(20)$ & \\
\hline $\mathrm{C}_{5}-\mathrm{N}_{7}-\mathrm{C}_{14}$ & 126.7 & $-^{\mathrm{f}}$ & $127.9(2)$ & & & \\
\hline $\mathrm{N}_{7}-\mathrm{C}_{8}-\mathrm{H}_{15}$ & 121.2 & $-^{f}$ & & & & \\
\hline$<\mathrm{N}-\mathrm{C}-\mathrm{H}_{\text {methyl }}>$ & 108.5 & $(28)$ & & & & \\
\hline
\end{tabular}

${ }^{a}$ See Fig. 1 for the atom numbering. Angle brackets denote average values.

Values in parentheses are estimated error limits referring to the last significant digit.

${ }^{\mathrm{b}}$ Ref. [26]. Some bond lengths were calculated from the listed $r_{\mathrm{a}}$ distances and 
the mean amplitudes, $l$.

${ }^{\mathrm{c}}$ Ref. [27]. Error limits were taken from ref. [28].

${ }^{\mathrm{d}}$ This work. Error limits are $3 \sigma$.

${ }^{\mathrm{e}}$ Caffeine hydrate. Taken from the supplementary data, CAFINE01.cif, of Ref. [8].

${ }^{\mathrm{f}}$ Dependent parameter. 


\section{Figure captions}

Fig. 1 Molecular models and atom numberings of caffeine and related molecules.

Shaded are the double bonds.

Fig. 2 Experimental (open circles) and theoretical (solid curve) molecular scattering intensities of caffeine; $\Delta s M(s)=s M(s)^{\text {obs }}-s M(s)^{\text {calc }}$. The theoretical curve was calculated from the best-fit parameters.

Fig. 3 Theoretical potential energies for the internal rotation of caffeine obtained by the MP2/6-31G** (closed circles) and B3LYP/6-31G** (open circles). Solid curves are the best-fit potential functions reproduced by using eq. (1). The angle $\phi$ for the internal rotation is defined as $\phi\left(\mathrm{C}_{6}-\mathrm{N}_{1}-\mathrm{C}_{10}-\mathrm{H}\right)$ for the $\mathrm{N}_{1}-\mathrm{C}_{10}$ bond, $\phi\left(\mathrm{C}_{4}-\mathrm{N}_{3}-\mathrm{C}_{12}-\mathrm{H}\right)$ for the $\mathrm{N}_{3}-\mathrm{C}_{12}$ bond and $\phi\left(\mathrm{C}_{8}-\mathrm{N}_{7}-\mathrm{C}_{14}-\mathrm{H}\right)$ for the $\mathrm{N}_{7}-\mathrm{C}_{14}$ bond.

Fig. 4 Experimental radial distribution curve of caffeine; $\Delta f(r)=f(r)^{\text {obs }}-f(r)^{\text {calc }}$. Distance distribution is indicated by vertical bars. 

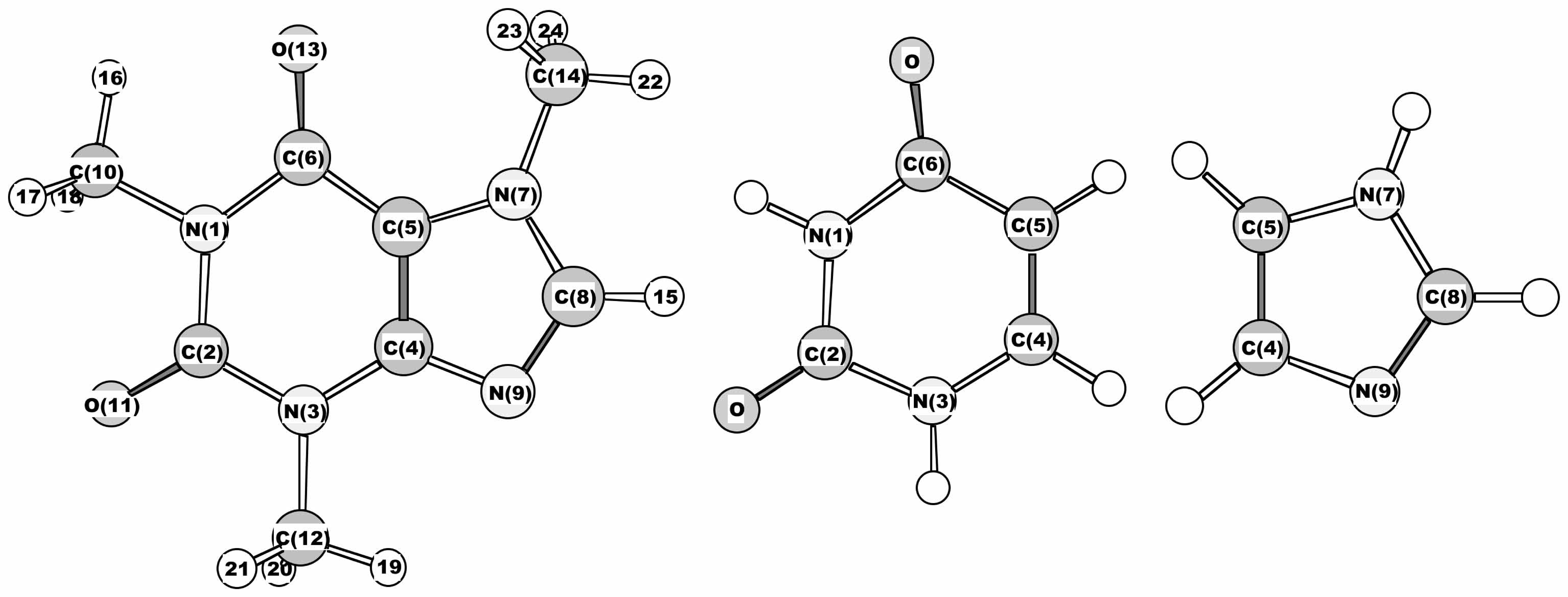


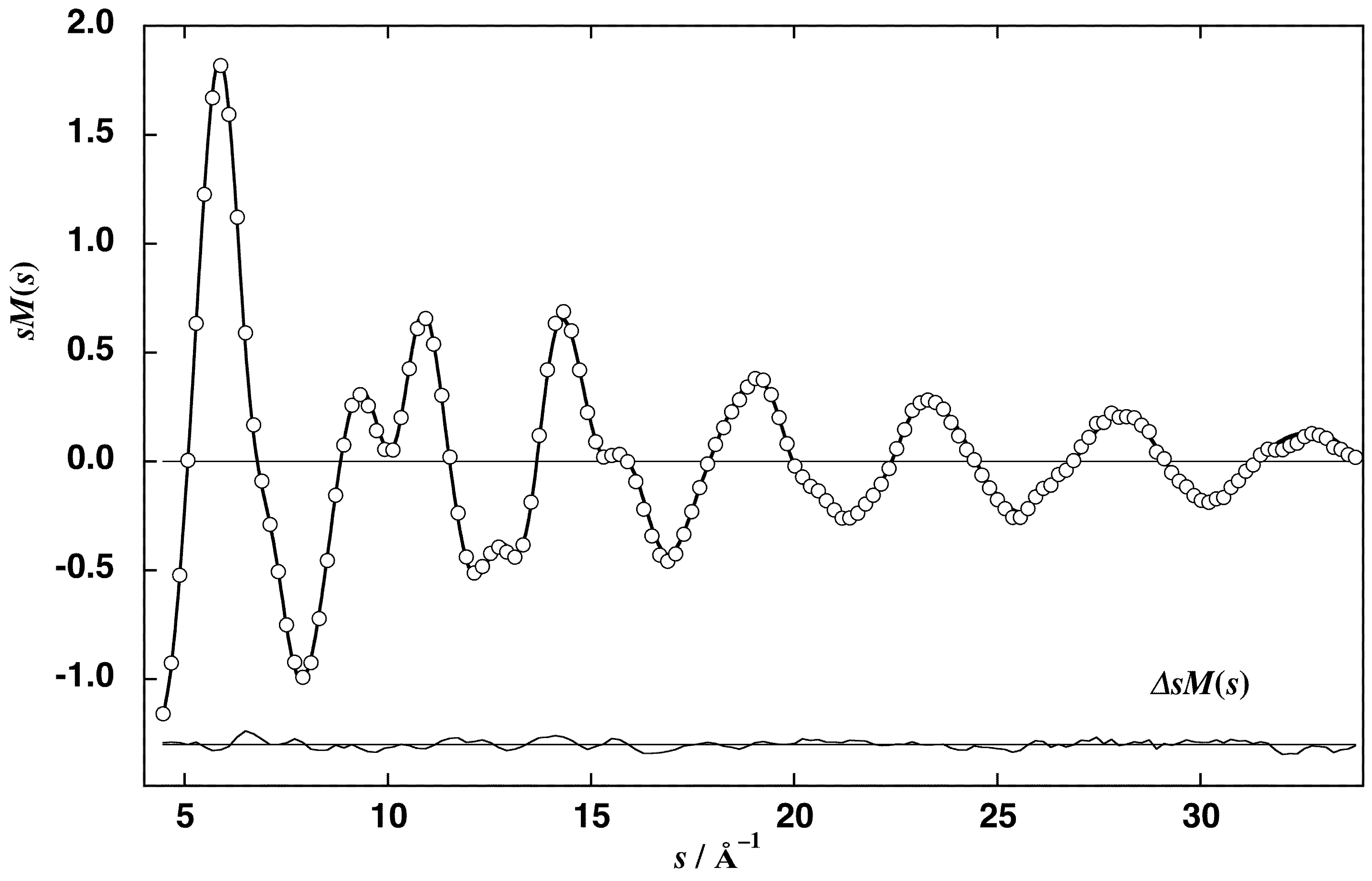




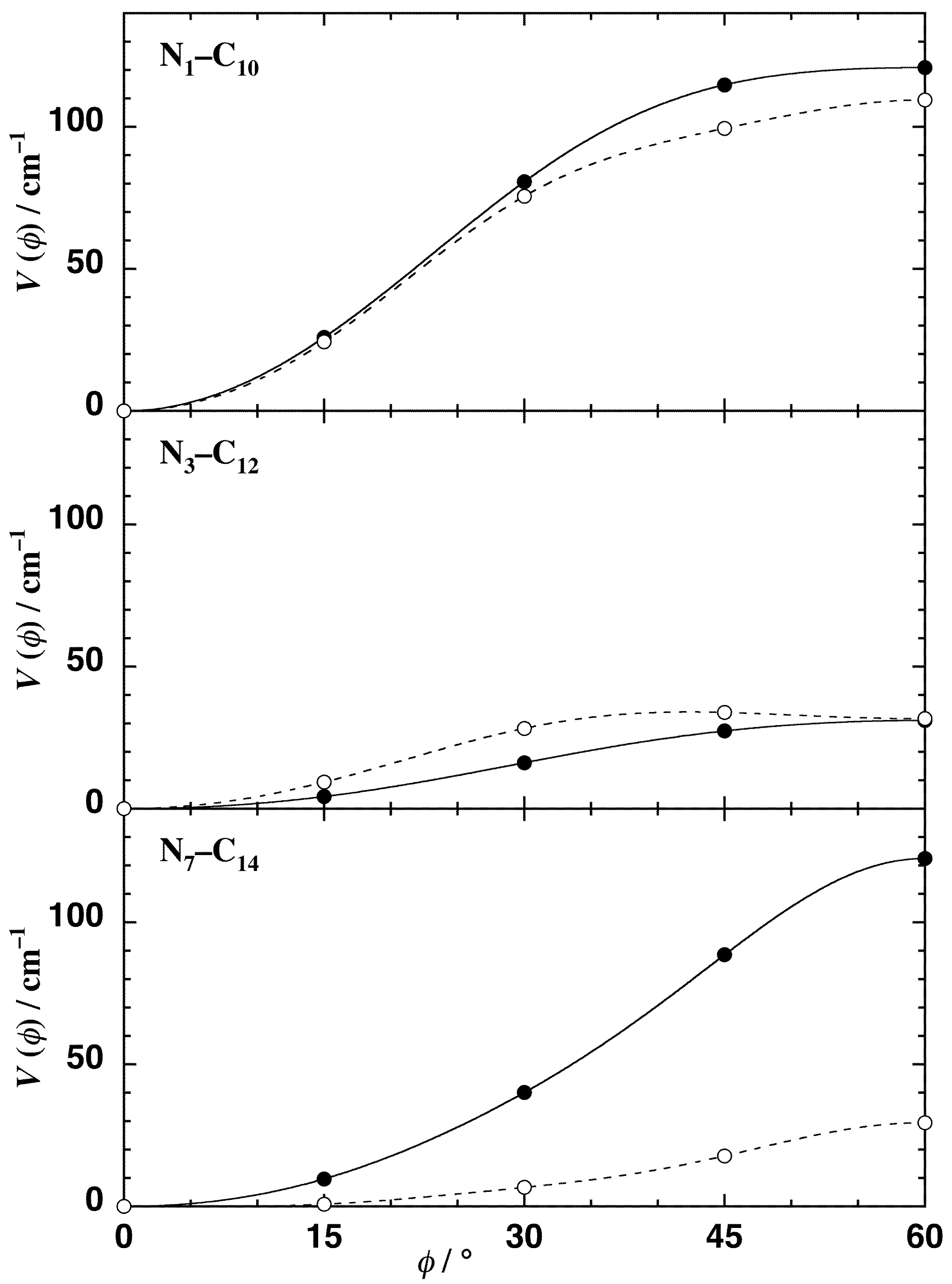


